\title{
THE ABSORPTION OF HEMOLYTIC AMBOCEPTOR.*
}

WILFRED H. MANWARING.

(From the Pathological Laboratory of the University of Chicago.)

As PART of a somewhat extended study of the physical chemistry of hemolytic serum, it was necessary to determine the amount of hemolytic amboceptor absorbed by corpuscles. The result of this determination being at variance with results recently published by Arrhenius ${ }^{1}$ its early publication is desirable. A more extended study of absorption phenomena will be reported later.

The serum used in this work was that of goats immunized against sheep corpuscles. The hemolytic experiments were performed in accordance with the technique adopted in this laboratory and described elsewhere in this issue. ${ }^{2}$

To determine the amount of amboceptor absorbed by corpuscles, varying amounts of heated hemolytic serum (amboceptor) were placed in large centrifuge tubes, the volumes made up to a constant $\left(10\right.$ c.c.) with $\frac{m}{8} \mathrm{NaCl}$-solution and a uniform amount of washed sheep corpuseles (seven c.c. of a seven per cent suspension of corpuscles No. 1) added to each. The tubes were shaken, incubated at $37.5^{\circ} \mathrm{C}$. for three hours and placed in the ice-chest over night, exactly as in the routine hemolytic experiment. The next morning the fluid in each tube was again mixed to insure its uniformity throughout, the corpuscles thrown down by centrifugation, and accurately measured quantities of the supernatant liquid removed for analysis.

The analysis was performed by means of the amboceptor curve. $^{3}$ This is the curve showing the changes in hemolytic power as the amboceptor increases in amount, and is obtained by exposing corpuscles to increasing quantities of amboceptor, in

*The first half of this paper was presented before the American Association of Patholo gists and Bacteriologists, April 22, 1905; the second half before the Chicago Pathological Society, June 12, 1905. Received for publication May 29, 1905.

1 Arbeiten aus dem Kaiserlichen Gesundheitsamte, Bd. XX, p. 5559.

2 See p. 462.

3 See p. 471. 
the presence of a constant amount of complement. The fluid to be analyzed was added to the same amount of complement, and the resulting hemolysis compared with readings on this curve.

Knowing the amount of amboceptor originally added to the corpuscles, the volume removed for analysis, and the amount of amboceptor found in this volume, the loss of amboceptor, or the amboceptor absorbed by the corpuscles can be readily calculated. A series of results obtained in this way are shown in Table 1 , and represented graphically in Fig. 1. The small figure in the upper part of Fig. 1 is the amboceptor curve used in the analysis.

TABLE 1.

Absorption of Amboceptor No. 1.

Recorded amounts of heated immune serum No. 1 placed in large centrifuge tubes, volumes made up to 10 c.c. with $\frac{m}{g} \mathrm{NaCl}, 7$ c. c. of a 7 per cent suspension of washed sheep corpuscles No. 1, added to each, recorded amounts removed for analysis. In calculating results allowance was made for volume of corpuscles $(0.14$ c.c.) and evaporation $(0.11$ c.c. $)$.

\begin{tabular}{|c|c|c|c|c|c|}
\hline Amboceptor & $\begin{array}{l}\text { Amount } \\
\text { Analyzed }\end{array}$ & Hemolysis & $\begin{array}{l}\text { Corresponding } \\
\text { Amboceptor }\end{array}$ & $\begin{array}{c}\text { Free } \\
\text { Amboceptor } \\
\text { (Average) }\end{array}$ & $\begin{array}{c}\text { Bound } \\
\text { Amboceptor } \\
\text { (Average) }\end{array}$ \\
\hline $\begin{array}{l}5.0 \text { c.c. } \\
4.0\end{array}$ & $\begin{array}{l}1 \text { c.c. } \\
1\end{array}$ & $\begin{array}{l}70.0 \% \\
44.0\end{array}$ & $\begin{array}{l}0.252 \text { c.c. } \\
0.196\end{array}$ & $\begin{array}{l}4.22 \text { c.c. } \\
3.28\end{array}$ & $\begin{array}{l}0.78 \text { c.c. } \\
0.72\end{array}$ \\
\hline 3.5 & $\left\{\begin{array}{l}1 \\
2\end{array}\right.$ & $\begin{array}{l}25.0 \\
95.0\end{array}$ & $\left.\begin{array}{l}0.154 \\
0.320\end{array}\right\}$ & 2.66 & 0.84 \\
\hline 2.5 & $\left\{\begin{array}{l}1 \\
2 \\
3\end{array}\right.$ & $\begin{array}{l}10.0 \\
43.0 \\
90.5\end{array}$ & $\left.\begin{array}{l}0.100 \\
0.194 \\
0.300\end{array}\right\}$ & 1.66 & 0.84 \\
\hline 2.0 & $\left\{\begin{array}{l}1 \\
2 \\
3\end{array}\right.$ & $\begin{array}{r}5.8 \\
19.0 \\
47.5\end{array}$ & $\left.\begin{array}{l}0.071 \\
0.138 \\
0.204\end{array}\right\}$ & 1.16 & 0.84 \\
\hline 1.5 & $\left\{\begin{array}{l}2 \\
3\end{array}\right.$ & $\begin{array}{r}9.0 \\
19.0\end{array}$ & $\left.\begin{array}{l}0.096 \\
0.138\end{array}\right\}$ & 0.79 & 0.71 \\
\hline 1.25 & $\left\{\begin{array}{l}2 \\
3\end{array}\right.$ & $\begin{array}{r}7.0 \\
11.0\end{array}$ & $\left.\begin{array}{l}0.080 \\
0.108\end{array}\right\}$ & 0.64 & 0.61 \\
\hline 1.0 & $\mathbf{3}$ & 6.0 & 0.076 & 0.42 & 0.58 \\
\hline 0.8 & 3 & 5.0 & 0.070 & 0.39 & 0.41 \\
\hline 0.6 & 3 & 4.0 & 0.052 & 0.29 & 0.31 \\
\hline 0.4 & 3 & $40-$ & 0.048 & 0.27 & 0.13 \\
\hline 0.2 & 3 & 3.0 & 0.030 & 0.17 & 0.08 \\
\hline
\end{tabular}

In a recent publication ${ }^{1}$ Arrhenius claims that this absorption takes place in accordance with certain well-established physicochemical laws, that, in brief, the amboceptor divides itself between corpuscles and surrounding fluid exactly as a dissolved substance divides itself between two immiscible solvents.

1 Loc. cit, 
To illustrate, if benzene and water are in contact and a substance soluble in both is added to one of them, the substance will divide itself between the two solvents in the ratio of its solubilities in the two fluids, provided, of course, no chemical change takes

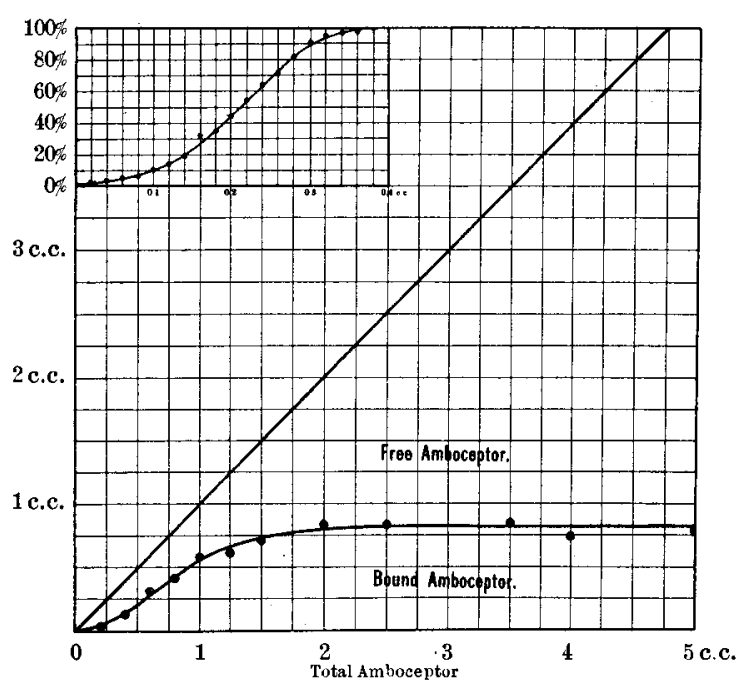

FIG. 1.-The absorption curve. (See Table 1.)

place in either liquid. Thus, if its solubility in water is $S$ grams per liter, and in benzene $S^{\prime}$ grams, division will take place so that

$$
\frac{\text { Concentration* in water }}{\text { Concentration in benzine }}=\frac{S}{S^{\prime}}=\mathrm{K} \text {, a constant. }
$$

To this constant, $\mathbf{K}$, the name Partition Coefficient, or Distribution Coefficient, has been given.

In many cases, however, solution is accompanied by chemical change in the dissolved substance. Thus, benzoic acid dissolved in water has the formula $\mathrm{C}_{6} \mathrm{H}_{5} \mathrm{COOH}$, but on dissolving it in benzine it polymerises to form $\left(\mathrm{C}_{6} \mathrm{H}_{5} \mathrm{COOH}\right)_{2}$. For such cases it can be deduced theoretically and verified experimentally ${ }^{1}$ that division takes place in accordance with the more complex formula

$$
\frac{\text { Concentration in water }}{{ }^{2} \sqrt{\text { Concentration in benzene }}}=\mathrm{K} \text {. }
$$

* Number of gram-molecules per liter.

1 Nennst, Theoretical Chemistry, second English edition (1901), p. 486. 
Similarly, if the dissolved substance should exist in benzene as a polymer of three molecules, division would take place so that

$$
\frac{\text { Concentration in wator }}{\sqrt[3]{\text { Concentration in benzene }}}=\mathrm{K} \text {. }
$$

A somwhat complex example, but one that illustrates closely the method of absorption claimed for amboceptor and agglutinins, is afforded by assuming that in one of the solvents (water), the substance exists as a polymer of three molecules, while in the other (benzene), it exists as a polymer of two. Division would then take place in accordance with the formula

$$
\frac{\sqrt[3]{\text { Concentration in water }}}{2^{2} \text { Concentration in benzene }}=\mathrm{K} \text {. }
$$

This, according to Arrhenius, is the equation governing the absorption of hemolytic amboceptor; amboceptor dividing itself between corpuscles and liquid so that

$$
\frac{\sqrt[3]{\text { Concentration in liquid }}}{\sqrt[2]{\text { Concentration in corpuscles }}}=\mathrm{K} \text {. }
$$

Using brackets to denote concentration, this may be expressed

$$
\frac{[\text { Free amboceptor }]^{1 / 3}}{[\text { Bound amboceptor }]^{1 / 2}}=\mathrm{K} \text {, }
$$

and may be simplified to read

$$
\frac{\left[_{\text {Free amboceptor }]^{2}}\right.}{\left[{\text { [Bound amboceptor }]^{3}}^{3}\right.}=\mathrm{K}^{6}=K .
$$

Applying this conception to the data obtained above, and calculating $K^{\prime}$, a multiple of $K$ obtained by omitting to divide by volumes - the volumes are constant throughout and this omission introduces no error-there are obtained values recorded in Table 2. It is seen that $K^{\prime}$ is not a constant, and that the absorption does not follow the physico-chemical law proposed.

Comparison between the observed absorption and the theoretical absorption of Arrhenius can best be made by calculating the bound amboceptor under the assumption that $K^{\prime}$ is constant. Table 3 gives such a comparison, the bound amboceptor being 
calculated from the observed free ambocepter by means of the value $K^{\prime}=2$. Other values of $K^{\prime}$ give even more strikingly dissimilar results.

TABLE 2.

\begin{tabular}{ccr}
\multicolumn{3}{c}{ Partition Cokffictent. } \\
Free Amboceptor & Bound Amboceptor & \multicolumn{1}{c}{$\boldsymbol{K}^{\prime}$} \\
4.22 c.c. & 0.78 c.c. & $\mathbf{3 7 . 5}$ \\
3.28 & 0.72 & $\mathbf{2 8 . 8}$ \\
2.66 & 0.84 & $\mathbf{1 1 . 0}$ \\
1.66 & 0.84 & 4.7 \\
1.16 & 0.84 & $\mathbf{2 . 3}$ \\
0.79 & 0.71 & $\mathbf{1 . 7}$ \\
0.64 & 0.61 & $\mathbf{1 . 9}$ \\
0.42 & 0.58 & $\mathbf{0 . 9}$ \\
0.39 & 0.41 & $\mathbf{2 . 2}$ \\
0.29 & 0.31 & $\mathbf{2 . 8}$ \\
0.27 & 0.13 & $\mathbf{3 3 . 2}$ \\
0.17 & 0.03 & $\mathbf{1 0 7 0 . 0}$
\end{tabular}

TABLE 3.

Observed Absorption and Calculated Absorption Compared.

Bound amboceptor calculated from the value $K^{\prime}=2$.

Free Amboceptor

4.22 c.c.
3.28
2.66
1.66
1.16
0.79
0.64
0.42
0.39
0.29
0.27
0.17

Bound Amboceptor (Observed)

0.78 c.c.

0.72

0.84

0.84

0.84

0.71

0.61

0.58

0.41

0.31

0.13

0.03
Bound Amboceptor

(Calculated)

2.07 c.c.

1.75

1.52

1.11

0.88

0.68

0.60

0.44

0.42

0.35

0.33

0.24

The same comparison is shown in Fig. 2, in which the heavy line, AB, represents the observed absorption, and the dotted line, AC, the calculated absorption. The curves agree roughly only when small amounts of amboceptor are used. With large amounts they diverge widely.

In repeating this experiment with immune serum No. 2, and increasing the amount of amboceptor to 10 c.c., a phenomenon 
was observed that throws doubt on the experimental method and strikingly illustrates the difficulty of attempting to apply elementary physico-chemical laws to phenomena of this nature, before all factors entering into the phenomena are known. In this experiment, when large quantities of serum were used, apparently as much amboceptor was found in the fluid as was added to it originally, and with still larger amounts, the paradoxical result was

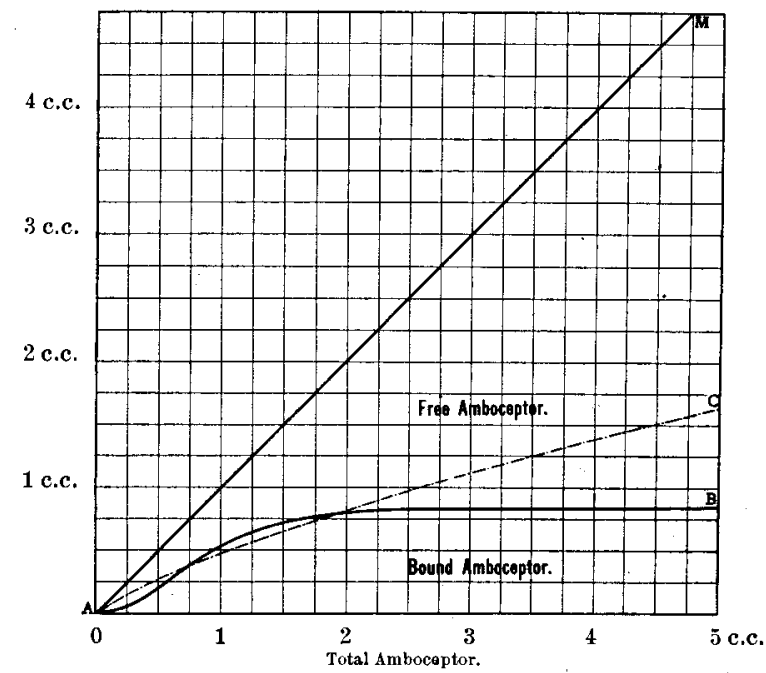

FIG. 2.-Absorption curve and physico-chemical curve compared. $A B=$ observed absorption $\mathrm{AC}=$ calculated absorption from the value $\mathrm{K}^{\prime}=\mathbf{2}$.

obtained that apparently more amboceptor was recovered than was put there in the first place. The data from this experiment are shown in Table 4, and represented graphically in Fig. 3.

An even more striking curve was obtained by using large amounts of immune serum No. 1. This curve is shown in Fig. 4.

On examining the data in Table 4 a very suggestive, though at first glance not a striking fact is evident, that of non-agreement of duplicates. (See Calculated Free Amboceptor.) When equal volumes of serum are used for analysis, duplicate analyses agree within the limits of experimental error. But when unequal volumes are used, the duplicates in all cases differ, the difference following the uniform rule that the smaller amount gives the higher result. 


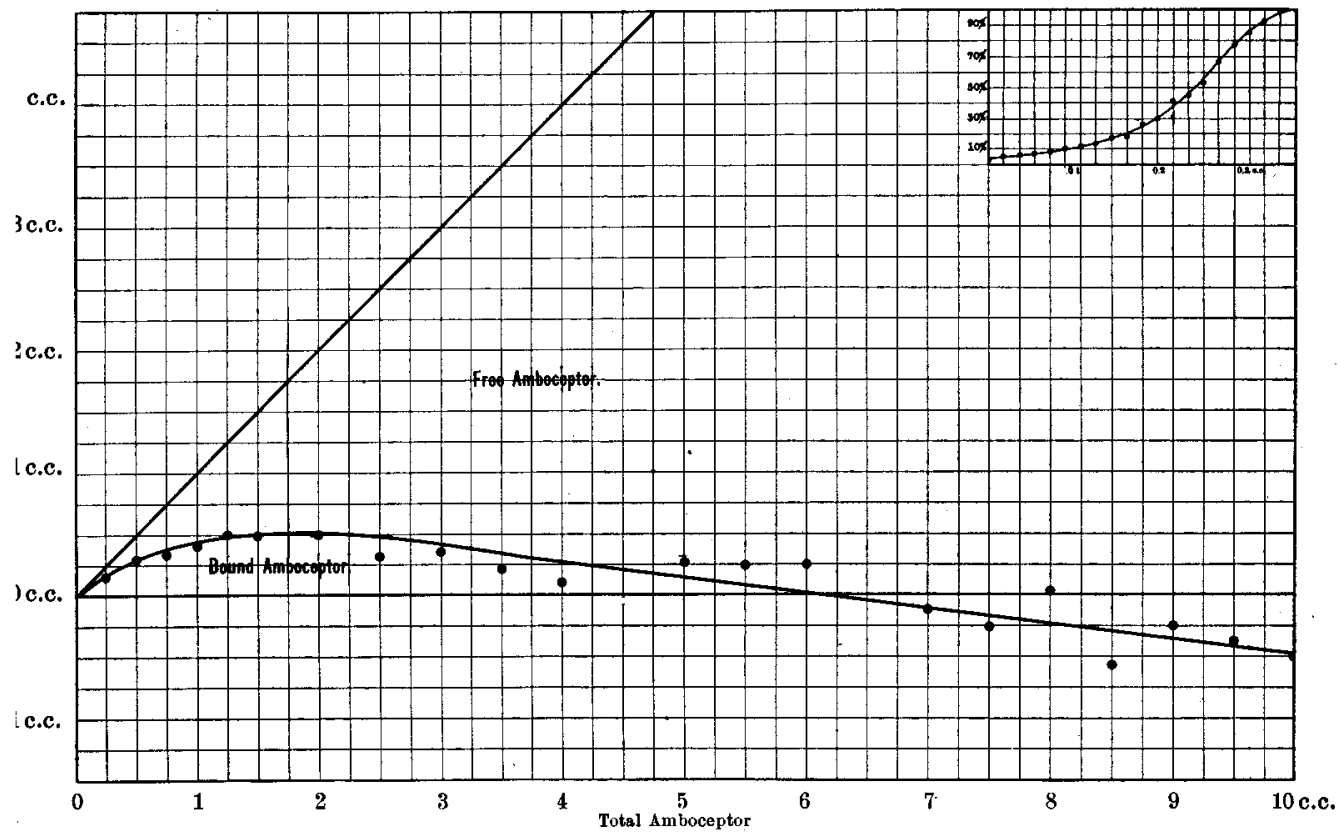

Frg. 3.-Absorption curve with large amounts of serum. (Amboceptor No. 2, see Table 4.)

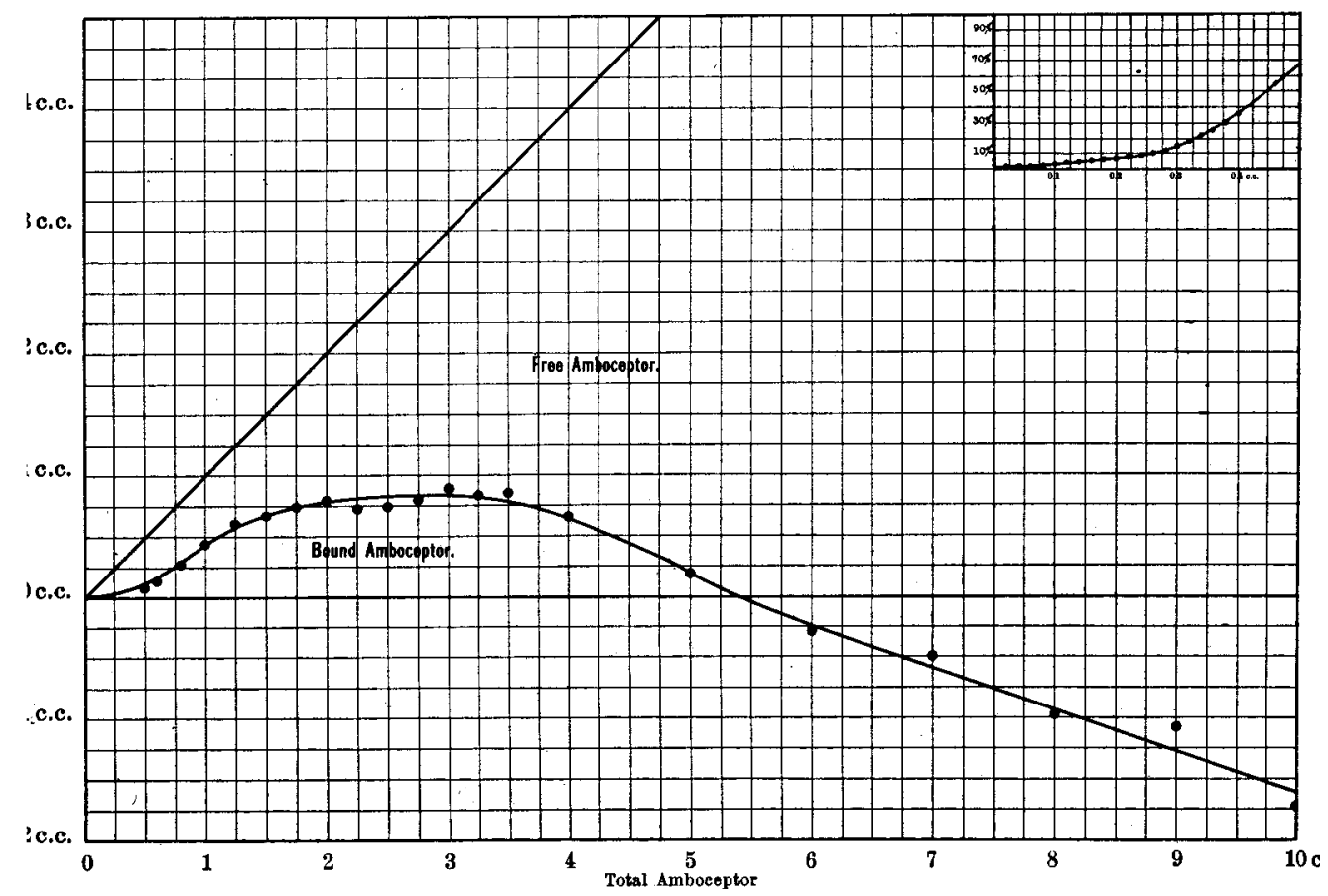

Fig. 4.-Absorption curve with large amounts of serum. (Amboceptor No. 1.) 
TABLE 4.

Absorption of Amboceptor No. 2. Corpuscles No. 1.

\begin{tabular}{|c|c|c|c|c|c|c|c|c|}
\hline \multirow{2}{*}{\multicolumn{2}{|c|}{$\begin{array}{l}\text { AMBO- } \\
\text { CEPTOR }\end{array}$}} & \multirow{2}{*}{ ANOUNT } & \multirow{2}{*}{$\begin{array}{l}\text { HEMOL: } \\
\text { YSIS }\end{array}$} & \multirow{2}{*}{$\begin{array}{l}\text { CORRE- } \\
\text { SPONDING } \\
\text { AMBO- } \\
\text { CEPTOR }\end{array}$} & \multicolumn{2}{|c|}{ Free Amboceptor } & \multirow{2}{*}{ BOUND } & \multirow{2}{*}{$\mathbf{K}^{\prime}$} \\
\hline & & & & & Calculated & Average & & \\
\hline 10 c.c & $\cdots$ & $\begin{array}{l}0.25 \text { c.c. } \\
0.30 \\
0.35\end{array}$ & $\begin{array}{l}20.5 \% \\
30.0 \\
33.8\end{array}$ & $\begin{array}{l}0.162 \text { c.c. } \\
0.194 \\
0.204\end{array}$ & $\left.\begin{array}{r}10.86 \\
10.80 \\
9.78\end{array}\right\}$ & 10.48 c.c. & $-0.48 \mathrm{c.c}$ & -993 \\
\hline 9.5 & .. & $\begin{array}{l}0.275 \\
0.325 \\
0.375\end{array}$ & $\begin{array}{l}24.2 \\
30.4 \\
35.9\end{array}$ & $\begin{array}{l}0.176 \\
0.194 \\
0.211\end{array}$ & $\left.\begin{array}{r}10.69 \\
9.50 \\
\mathbf{9 . 4 1}\end{array}\right\}$ & 9.87 & -0.37 & -1923 \\
\hline 9.0 & .. & $\begin{array}{l}0.30 \\
0.35 \\
0.40\end{array}$ & $\begin{array}{l}24.0 \\
29.0 \\
36.4\end{array}$ & $\begin{array}{l}0.175 \\
0.191 \\
0.212\end{array}$ & $\left.\begin{array}{r}9.75 \\
9.12 \\
8.87\end{array}\right\}$ & 9.25 & -0.25 & -5351 \\
\hline 8.5 &.. & $\begin{array}{l}0.30 \\
0.35 \\
0.40\end{array}$ & $\begin{array}{l}23.5 \\
29.3 \\
33.5\end{array}$ & $\begin{array}{l}0.173 \\
0.191 \\
0.203\end{array}$ & $\left.\begin{array}{l}9.65 \\
9.13 \\
8.53\end{array}\right\}$ & 9.10 & -0.60 & -383 \\
\hline 8.0 & .. & $\begin{array}{l}0.30 \\
0.35 \\
0.40\end{array}$ & $\begin{array}{r}17.5 \\
22.8 \\
-29.0\end{array}$ & $\begin{array}{l}0.148 \\
0.170 \\
0.191\end{array}$ & $\left.\begin{array}{l}8.24 \\
8.14 \\
7.69\end{array}\right\}$ & 8.02 & -0.02 & -6386 \\
\hline 7.5 & .. & $\begin{array}{l}0.35 \\
0.40 \\
0.45\end{array}$ & $\begin{array}{l}21.8 \\
27.3 \\
33.5\end{array}$ & $\begin{array}{l}0.167 \\
0.185 \\
0.203\end{array}$ & $\left.\begin{array}{l}7.97 \\
7.72 \\
7.57\end{array}\right\}$ & 7.75 & -0.25 & -3844 \\
\hline 7.0 &.. & $\begin{array}{l}0.40 \\
0.45 \\
0.50\end{array}$ & $\begin{array}{l}24.0 \\
28.8 \\
34.5\end{array}$ & $\begin{array}{l}0.175 \\
0.189 \\
0.207\end{array}$ & $\left.\begin{array}{l}7.32 \\
7.04 \\
6.94\end{array}\right\}$ & 7.10 & -0.10 & -50410 \\
\hline 6.0 &.. & $\begin{array}{l}0.4 \\
0.5 \\
0.6\end{array}$ & $\begin{array}{l}16.0 \\
23.5 \\
30.0\end{array}$ & $\begin{array}{l}0.140 \\
0.173 \\
0.198\end{array}$ & $\left.\begin{array}{l}5.88 \\
5.80 \\
5.03\end{array}\right\}$ & 5.74 & 0.26 & 1875 \\
\hline 5.5 &. & $\begin{array}{l}0.5 \\
0.6 \\
0.7\end{array}$ & $\begin{array}{l}21.0 \\
29.3 \\
35.0\end{array}$ & $\begin{array}{l}0.164 \\
0.191 \\
0.208\end{array}$ & $\left.\begin{array}{l}5.49 \\
5.33 \\
4.98\end{array}\right\}$ & 5.27 & 0.23 & 2282 \\
\hline 5.0 & $\ldots$ & $\begin{array}{l}0.6 \\
0.7 \\
0.8\end{array}$ & $\begin{array}{l}23.8 \\
33.5 \\
37.5\end{array}$ & $\begin{array}{l}0.174 \\
0.203 \\
0.214\end{array}$ & $\left.\begin{array}{l}4.84 \\
4.88 \\
4.49\end{array}\right\}$ & 4.74 & 0.26 & 1278 \\
\hline 4.5 &.. & $\begin{array}{l}0.7 \\
0.75 \\
0.9\end{array}$ & $\begin{array}{l}26.0 \\
27.5 \\
36.4\end{array}$ & $\begin{array}{l}0.182 \\
0.185 \\
0.211\end{array}$ & $\left.\begin{array}{l}4.36 \\
4.14 \\
3.92\end{array}\right\}$ & 4.14 & 0.26 & 975 \\
\hline 4.0 &.. & $\begin{array}{l}0.7 \\
0.8 \\
1.0\end{array}$ & $\begin{array}{l}22.5 \\
30.8 \\
40.0\end{array}$ & $\begin{array}{l}0.169 \\
0.196 \\
0.220\end{array}$ & $\left.\begin{array}{l}4.06 \\
4.02 \\
3.67\end{array}\right\}$ & 3.92 & 0.08 & 30010 \\
\hline 3.5 &.. & $\begin{array}{l}0.8 \\
1.0 \\
1.2\end{array}$ & $\begin{array}{l}24.8 \\
27.5 \\
40.5\end{array}$ & $\begin{array}{l}0.178 \\
0.185 \\
0.221\end{array}$ & $\left.\begin{array}{l}3.74 \\
3.10 \\
3.08\end{array}\right\}$ & 3.31 & 0.19 & 1597 \\
\hline 3.0 & .. & $\begin{array}{l}1.0 \\
1.2 \\
1.4\end{array}$ & $\begin{array}{l}21.0 \\
31.0 \\
36.3\end{array}$ & $\begin{array}{l}0.164 \\
0.196 \\
0.212\end{array}$ & $\left.\begin{array}{l}2.75 \\
2.73 \\
2.47\end{array}\right\}$ & 2.65 & 0.35 & 160 \\
\hline 2.5 &.. & $\begin{array}{l}1.5 \\
1.75 \\
2.0\end{array}$ & $\begin{array}{l}26.5 \\
32.5 \\
42.0\end{array}$ & $\begin{array}{l}0.182 \\
0.200 \\
0.225\end{array}$ & $\left.\begin{array}{l}2.03 \\
1.91 \\
1.89\end{array}\right\}$ & 1.94 & 0.31 & 126 \\
\hline 2.0 & .. & $\begin{array}{l}2.0 \\
2.5 \\
3.0\end{array}$ & $\begin{array}{l}29.0 \\
43.0 \\
52.5\end{array}$ & $\begin{array}{l}0.189 \\
0.227 \\
0.247\end{array}$ & $\left.\begin{array}{l}1.69 \\
1.53 \\
1.37\end{array}\right\}$ & 1.49 & 0.51 & 17 \\
\hline 1.5 &.. & $\begin{array}{l}3.0 \\
3.5 \\
4.0\end{array}$ & $\begin{array}{l}31.1 \\
34.5 \\
41.3\end{array}$ & $\begin{array}{l}0.198 \\
0.207 \\
0.223\end{array}$ & $\left.\begin{array}{l}1.11 \\
9.99 \\
0.94\end{array}\right\}$ & 1.01 & 0.49 & 9 \\
\hline
\end{tabular}


TABLE 4-Continued.

\begin{tabular}{|c|c|c|c|c|c|c|c|}
\hline \multirow{2}{*}{$\underset{\text { CEPTOR }}{\text { AMBO- }}$} & \multirow{2}{*}{$\begin{array}{l}\text { AMOUNT } \\
\text { ANAIXZED }\end{array}$} & \multirow{2}{*}{$\begin{array}{l}\text { HEMOL- } \\
\text { YSIS }\end{array}$} & \multirow{2}{*}{$\begin{array}{l}\text { CORRE- } \\
\text { SPONDING } \\
\text { AMBO- } \\
\text { CEPTOR }\end{array}$} & \multicolumn{2}{|c|}{ FREE AMBOCEPTOR } & \multirow{2}{*}{$\begin{array}{c}\text { BOUND } \\
\text { AMBOCEPTOR }\end{array}$} & \multirow{2}{*}{$\mathbf{K}^{\prime}$} \\
\hline & & & & Calculated & Average & & \\
\hline $1.25 \mathrm{c.c} .$. & $\begin{array}{ll}3.0 & \text { c.c. } \\
3.5 & \\
4.0 & \end{array}$ & $\begin{array}{l}18.0 \\
22.0 \\
23.0\end{array}$ & $\begin{array}{l}0.151 \\
0.167 \\
0.173\end{array}$ & $\left.\begin{array}{l}0.84 \\
0.80 \\
0.69\end{array}\right\}$ & 0.78 & 0.47 & 5.9 \\
\hline 1.0 & $\begin{array}{l}3.5 \\
3.75 \\
4.0\end{array}$ & $\begin{array}{l}13.8 \\
14.3 \\
15.3\end{array}$ & $\begin{array}{l}0.124 \\
0.128 \\
0.137\end{array}$ & $\left.\begin{array}{l}0.60 \\
0.57 \\
0.57\end{array}\right\}$ & 0.58 & 0.42 & 4.5 \\
\hline 0.75 & $\begin{array}{l}4.0 \\
4.0 \\
4.0\end{array}$ & $\begin{array}{l}10.5 \\
10.0 \\
10.3\end{array}$ & $\begin{array}{l}0.097 \\
0.092 \\
0.095\end{array}$ & $\left.\begin{array}{l}0.41 \\
0.39 \\
0.40\end{array}\right\}$ & 0.40 & 0.35 & 3.7 \\
\hline 0.5 & $\begin{array}{l}4.0 \\
4.0 \\
4.0\end{array}$ & $\begin{array}{l}6.5 \\
6.5 \\
6.5\end{array}$ & $\begin{array}{l}0.047 \\
0.047 \\
0.047\end{array}$ & $\left.\begin{array}{l}0.20 \\
0.20 \\
0.20\end{array}\right\}$ & 0.20 & 0.30 & 1.5 \\
\hline 0.25 & $\begin{array}{l}4.0 \\
4.0 \\
4.0\end{array}$ & $\begin{array}{l}4.8 \\
4.8 \\
4.8\end{array}$ & $\begin{array}{l}0.018 \\
0.018 \\
0.018\end{array}$ & $\left.\begin{array}{l}0.08 \\
0.08 \\
0.08\end{array}\right\}$ & 0.08 & 0.17 & 1.6 \\
\hline
\end{tabular}

From this it was suspected that there were qualitative as well as quantitative changes in the ambocepter and that these qualitative changes might render direct analysis impossible. To test this hypothesis, amboceptor curves were run with serum before and after contact with corpuscles. Two such curves are shown in

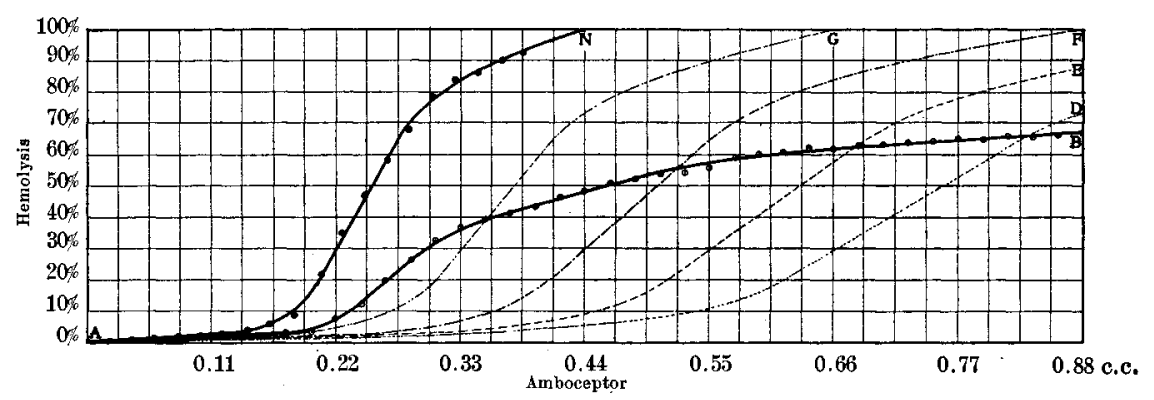

FIG. 5. - Amboceptor curves before and after contact with corpuscles. (Serum No. 1.) $\mathrm{AN}=$ normal amboceptor curve. $\mathrm{AB}=$ curve after exposure to corpuscles. Dotted curves $=$ theoretical curves representing quantitative changes only $(\mathrm{AD}=33 \mathrm{x} / \mathrm{s}, \mathrm{AE}=40 \%, \mathrm{AF}=$ $50 \%, \mathrm{AG}=66 \% \%$.

Fig. 5, AN being the normal amboceptor curve (before contact) and $\mathrm{AB}$ the amboceptor curve after exposure to corpuscles. It is needless to say that the two curves were made with the same serum, the same corpuscles, and on the same day. 
The qualitative differences between the two curves are made more evident by drawing theoretical curves under the assumption that there are quantitative changes only in the amboceptor. Four such curves are shown: AD representing the hemolysis under the assumption that the amboceptor is but a third its original strength, $\mathrm{AE}$ under the assumption that it is 40 per cent its original strength, $\mathrm{AF}$ that it is 50 per cent, and $\mathrm{AG}$ that it is $66_{3}^{2}$ per cent. These curves were obtained by multiplying the abscissas of $\mathrm{AN}$ by a constant factor, the ordinates remaining unchanged; but they agree perfectly with experimental curves obtained by using dilute serum.

From Fig. 5 it is seen that if a certain amount of altered serum were used for analysis the percentage of hemolysis would indicate that the amboceptor was over two-thirds its normal strength, if a larger volume were used it would apparently be but half its normal strength, and still larger amounts would give but 40 per cent or even less than $33 \frac{1}{3}$ per cent. A series of amboceptor strengths calculated from Fig. 5 is shown in Table 5, from which the impossibility of direct quantitative analysis is evident.

TABLE 5.

Amboceptor Strength.

\begin{tabular}{ccc}
\multicolumn{3}{c}{ Serum No. 1, Corpuscles No. 2 (See Fig. 5). } \\
Volume analyzed & Amboceptor found & Percentage \\
0.880 c.c. & 0.279 c.c. & $\mathbf{3 2} \%$ \\
0.825 & 0.278 & $\mathbf{3 4}$ \\
0.770 & 0.277 & $\mathbf{3 6}$ \\
0.715 & 0.273 & $\mathbf{3 8}$ \\
0.660 & 0.271 & $\mathbf{4 1}$ \\
0.605 & 0.269 & $\mathbf{4 4}$ \\
0.550 & 0.264 & $\mathbf{4 8}$ \\
0.495 & 0.257 & $\mathbf{5 2}$ \\
0.440 & 0.249 & $\mathbf{5 7}$ \\
0.385 & 0.240 & $\mathbf{6 2}$ \\
0.330 & 0.229 & $\mathbf{6 9}$ \\
0.275 & 0.209 & $\mathbf{7 6}$ \\
0.220 & 0.169 & $\mathbf{7 7}$
\end{tabular}

A second series of curves, made from immune serum No. 2, is shown in Fig. 6, and corresponding strengths of amboceptor in Table 6. 


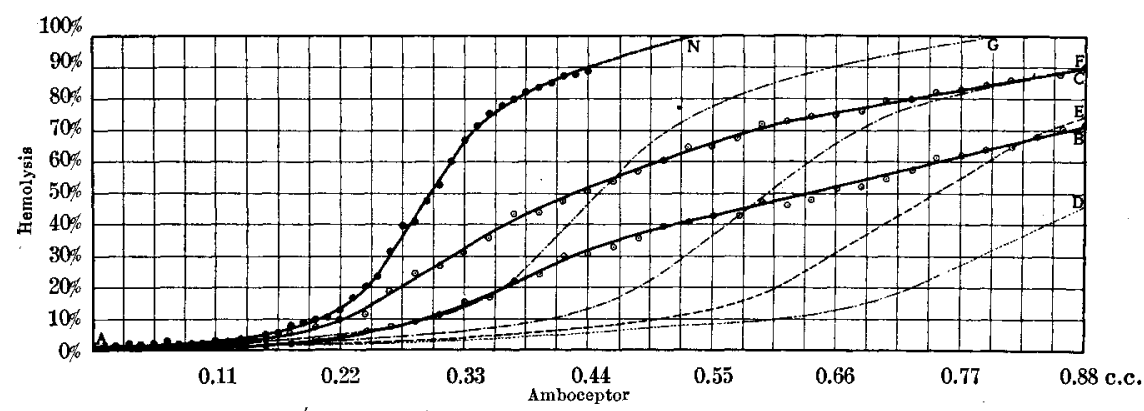

Fic.6.-Amboceptor curves before and after contact with corpuscles. (Serum No. 2.) $A N=$ normal amboceptor curve. $A B$ and $A C=$ curves after exposure to corpuscles. AC was obtained with half the number of corpuscles used in AB. Dotted curves as in Fig. 5 .

TABLE 6 .

AMboceptor Strength.

Serum No. 2, Corpuscles No 2 (See Fig. 6).

\begin{tabular}{|c|c|c|c|}
\hline \multirow{13}{*}{$A B$} & Volume analyzed & Amboceptor found & Percentag \\
\hline & 0.880 c.c. & 0.343 c.c. & $\mathbf{3 9} \%$ \\
\hline & 0.825 & 0.330 & 40 \\
\hline & 0.770 & 0.323 & 42 \\
\hline & 0.715 & 0.314 & 44 \\
\hline & 0.660 & 0.303 & 46 \\
\hline & 0.605 & 0.297 & 49 \\
\hline & 0.550 & 0.288 & 53 \\
\hline & 0.495 & 0.279 & 57 \\
\hline & 0.440 & 0.266 & 61 \\
\hline & 0.385 & 0.251 & 65 \\
\hline & 0.330 & 0.224 & 68 \\
\hline & 0.275 & 0.189 & 69 \\
\hline \multirow[t]{13}{*}{ AC. } & 0.880 c.c. & 0.440 c.c. & $50 \%$ \\
\hline & 0.825 & 0.413 & 50 \\
\hline & 0.770 & 0.391 & 51 \\
\hline & 0.715 & 0.370 & 52 \\
\hline & 0.660 & 0.356 & 54 \\
\hline & 0.605 & 0.343 & 57 \\
\hline & 0.550 & 0,330 & 60 \\
\hline & 0.495 & 0.315 & 63 \\
\hline & 0.440 & 0.303 & 69 \\
\hline & 0.385 & 0.288 & 75 \\
\hline & 0.330 & 0.268 & 81 \\
\hline & 0.275 & 0.244 & 89 \\
\hline & 0.220 & 0.198 & 90 \\
\hline
\end{tabular}

Not only do the curves show qualitative changes, but when serum and corpuscles are put together in certain proportions 
the new curve may actually cross the original curve, so that analysis might show more amboceptor than was originally present. Two such curves are shown in Fig. 7, and the corresponding strengths of amboceptor in Table 7. It was the accidental selection of volumes to be analyzed, so as to cause the analysis to fall in the crossed portion of the curve, that gave the paradoxical result noted above.

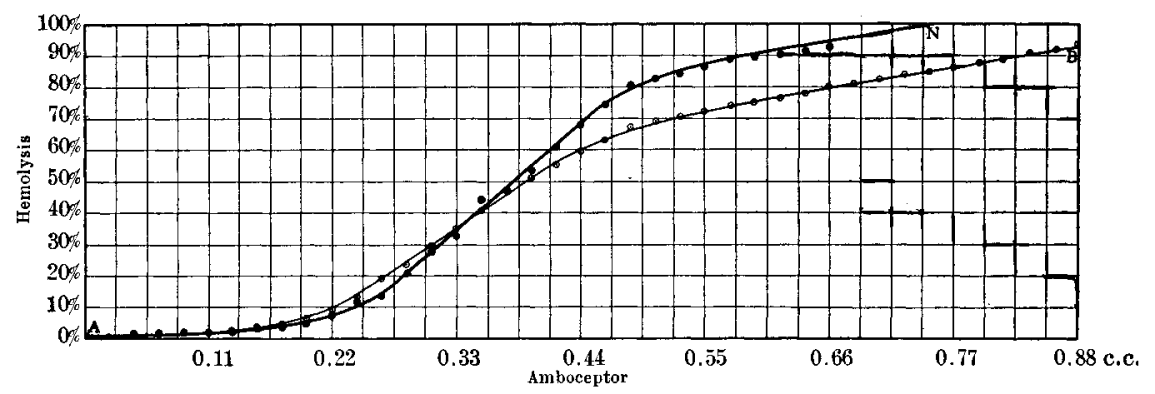

FIG. 7.- Paradoxical amboceptor curves. (Serum No. 2.) AN = normal amboceptor curve. $\mathrm{AB}=$ curve after exposure to a minimal number of corpuscles.

TABLE ?.

The Paradoxical Amboceptor

Serum No. 2, Corpuscles No. 2 (See Fig. 7).

$\begin{array}{ccc}\text { Volume analyzed } & \text { Amboceptor found } & \text { Percentage } \\ 0.880 \text { c.c. } & 0.627 \text { c.c. } & 70 \% \\ 0.825 & 0.585 & 71 \\ 0.770 & 0.546 & 71 \\ 0.715 & 0.515 & 72 \\ 0.660 & 0.491 & 74 \\ 0.605 & 0.468 & \mathbf{7 7} \\ 0.550 & 0.449 & \mathbf{8 2} \\ 0.495 & 0.436 & \mathbf{8 8} \\ 0.440 & 0.413 & \mathbf{9 4} \\ 0.385 & 0.374 & \mathbf{9 7} \\ 0.330 & 0.334 & \mathbf{1 0 1} \\ 0.3025 & 0.310 & \mathbf{1 0 2} \\ 0.275 & 0.290 & \mathbf{1 0 6} \\ 0.2475 & 0.270 & \mathbf{1 0 9} \\ 0.220 & 0.242 & \mathbf{1 1 0} \\ 0.1925 & 0.216 & \mathbf{1 1 2} \\ 0.165 & 0.187 & \mathbf{1 1 3}\end{array}$


This crossing of the curves was very marked in a number of experiments with the corpuscles of a certain somewhat anemic sheep (No. 1), but was slight and was obtained only after a number of trials with different amounts, with the corpuscles of a second animal (No. 2). The curves in Fig. 7 were obtained with the second corpuscles.

The nature of the change in the amboceptor and means of overcoming it and thus making analyses possible are now under investigation.

\section{SUMMARY.}

1. Using a method of analysis involving direct quantitative comparisons between treated and untreated serum, measurements are obtained not in accord with the physico-chemical law recently proposed by Arrhenius for the absorption of hemolytic amboceptor.

2. Heated hemolytic serum (amboceptor) is so changed by contact with corpuscles that any direct quantitative comparison between it and untreated serum gives erroneous results.

3. This fact makes the value of measurements thus far obtained for the absorption of hemolytic amboceptor exceedingly doubtful, and necessitates a re-examination of data of quantitative work with agglutinins, toxine-antitoxine mixtures, and various hemolysins, to rule out a possible similar source of error. 